\title{
Pengendalian hama penggerek ubi jalar Cylas formicarius (Fabricus) (Coleoptera: Curculionidae) menggunakan cendawan entomopatogen Beauveria bassiana (Balsamo) Vuillemin
}

\author{
The control of sweetpotato weevils Cylas formicarius (Fabricus) \\ (Coleoptera: Curculionidae) using entomopathogenic \\ fungi Beauveria bassiana (Balsamo) Vuillemin \\ Marida Santi Yudha Ika Bayu*, Yusmani Prayogo \\ Balai Penelitian Tanaman Aneka Kacang dan Umbi \\ Jalan Raya Kendalpayak, KM. 8, Kotak Pos. 66, Malang 65101 \\ (diterima April 2015, disetujui Januari 2016)
}

\begin{abstract}
ABSTRAK
Cylas formicarius (Fabricus) (Coleoptera: Curculionidae) merupakan hama utama ubi jalar yang menyebabkan kehilangan hasil hingga mencapai $100 \%$. Penelitian ini bertujuan untuk mendapatkan teknik pengendalian C. formicarius yang efektif dan efisien. Penelitian dilaksanakan bulan JuniOktober 2014 di kebun percobaan Muneng, Probolinggo, Jawa Timur, menggunakan rancangan acak kelompok, lima perlakuan diulang tiga kali. Perlakuannya adalah perendaman stek ubi jalar dalam suspensi konidia Beauveria bassiana (Bals.) Vuill. selama 30 menit sebelum tanam; aplikasi suspensi konidia $B$. bassiana ke tanah pada umur 2, 4, 6, 8, 10, dan 12 minggu setelah tanam; stek direndam suspensi konidia $B$. bassiana selama 30 menit sebelum tanam dilanjutkan aplikasi suspensi konidia $B$. bassiana ke tanah pada umur 2, 4, 6, 8, 10, dan 12 MST; aplikasi insektisida interval 1 minggu, kontrol. Hasil analisis ragam menunjukkan bahwa aplikasi berbagai jenis teknik pengendalian berpengaruh nyata terhadap populasi larva dan imago $C$. formicarius serta tingkat kerusakan umbi. Populasi $C$. formicarius pada umbi dari seluruh perlakuan berkisar antara 1-4 telur/tanaman, 1-19 larva/tanaman, 0-0,2 pupa/tanaman, dan 0-4 imago/tanaman. Bobot umbi per tanaman berkisar antara 571-700 g dan tingkat kerusakan umbi berkisar antara 5,83-53,33\%. Tingkat kerusakan umbi yang terendah terdapat pada perlakuan aplikasi suspensi konidia $B$. bassiana ke tanah atau pangkal batang ubi jalar pada umur $2,4,6,8,10$, dan $12 \mathrm{MST}$, yaitu hanya $6 \%$. Aplikasi suspensi konidia $B$. bassiana pada permukaan tanah atau pangkal batang ubi jalar pada umur 2, 4, 6, 8, 10, dan 12 MST berhasil menekan populasi C. formicarius pada umbi dan mengurangi kerusakan umbi ubi jalar hingga $48 \%$.
\end{abstract}

Kata kunci: Beauveria bassiana, Cylas formicarius, pengendalian mikroba, persistensi, stadia inang

\begin{abstract}
Cylas formicarius (Fabricus) (Coleoptera: Curculionidae) is one of the major pest on sweetpotato which can cause yield lost up to $100 \%$. The objective of this study was to obtain the effective and efficiency control technique of sweetpotato weevils. The research was conducted on June-October 2014 at Muneng Research Station, Probolinggo, East Java, using randomized block design, five treatments and three replicates. The treatments consisted of immersion of sweetpotato cuttings in the suspension of conidia Beauveria bassiana (Bals.) Vuill. for 30 minutes before planting; application of suspension of conidia $B$. bassiana on soil at 2, 4, 6, 8, 10, and 12 weeks after sowing (WAS); immersion of sweetpotato cuttings in the suspension of conidia $B$. bassiana for 30 minutes before
\end{abstract}

\footnotetext{
*Penulis korespondensi: Marida Santi Yudha Ika Bayu. Balai Penelitian Tanaman Aneka Kacang dan Umbi

Jalan Raya Kendalpayak, KM. 8, Kotak Pos 66, Malang 65101

Tel: 0341-801468,Faks: 0341-801496,Email: santi4_nov@yahoo.co.id
} 
planting combined with application of suspension of conidia $B$. bassiana on soil at 2, 4, 6, 8, 10, and 12 WAS; application of chemical insecticide every week; and control. Analysis of variance showed that the application of various control technique significantly lowered the population of larvae and imago of $C$. formicarius and the level of tuber damage. The population level found on all treatments ranged from 1-4 eggs/plant, 1-19 larvae/plant, 0-0.2 pupae/plant and 0-4 imago/plant. The weight of tuber was 571-700 g/plant with the level of damage 6-53\%. Low level of damage was found in the aplication of suspension of conidia B. bassiana on soil at 2, 4, 6, 8, 10, and 12 WAS which were $6 \%$. Application of suspension of conidia $B$. bassiana on soil at 2, 4, 6, 8, 10, and 12 WAS can suppress the population of $C$. formicarius on tuber and reduce the level of damage up to $48 \%$.

Key words: Beauveria bassiana, Cylas formicarius, host stage, microbial control, persistence

\section{PENDAHULUAN}

Hama boleng, Cylas formicarius (Fabricus) (Coleoptera: Curculionidae) merupakan hama utama ubi jalar di seluruh dunia (Kandori et al. 2006; Sharah et al. 2012). Hama ini tersebar luas di Amerika Utara, Amerika Tengah, Eropa, Afrika, dan Asia (Capinera 1998). C. formicarius dapat menyebabkan kehilangan hasil ubi jalar hingga mencapai 100\% (Chiranjeevi et al. 2003). Di Indonesia, kehilangan hasil yang diakibatkan oleh serangan C. formicarius mencapai 90\% (Nonci 2005). Stadia $C$. formicarius yang menyerang ubi jalar adalah larva. Larva C. formicarius menghabiskan siklus hidupnya di dalam umbi dan memakan umbi dengan membuat liang-liang gerekan. Umbi yang terserang terasa pahit dan tidak laku dijual. C. formicarius tidak hanya menyerang umbi di lapangan tapi juga menimbulkan kerusakan berat di tempat penyimpanan.

Teknik pengendalian $C$. formicarius yang dilakukan petani adalah menggunakan insektisida kimia. Hingga saat ini penggunaan insektisida kimia belum mampu mengendalikan C. formicarius secara signifikan (Leng \& Reddy 2012), sedangkan insektisida kimia yang diaplikasikan secara terus menerus justru dapat meningkatkan resistensi hama dan residunya berbahaya bagi lingkungan serta kesehatan manusia (Norris et al. 2003). Penggunaan insektisida kimia dalam mengendalikan C. formicarius pada tanaman ubi jalar tidak efektif karena larva $C$. formicarius menyerang di dalam umbi sehingga aplikasinya tidak tepat sasaran (Capinera 1998). Oleh karena itu, diperlukan teknik yang lebih efektif serta ramah lingkungan.

Pengendalian biologis menggunakan cendawan entomopatogen Beauveria bassiana merupakan salah satu upaya yang telah dikembangkan untuk mengendalikan C. formicarius (Ratissa 2011; Ahdiaty 2013). B. bassiana memiliki kisaran inang yang luas dan efektif terhadap bebagai jenis hama pada tanaman maupun dalam penyimpanan (Hansen \& Steenberg 2007). B. bassiana mampu menginfeksi hampir semua ordo serangga pada berbagai stadia (Gayathri et al. 2010; Tamuli \& Gurusubramanium 2011). Oleh karena itu, $B$. bassiana cukup prospektif digunakan sebagai alternatif pengendalian untuk mengurangi penggunaan insektisida kimia karena bersifat infektif serta aman terhadap lingkungan (Meyling \& Eilenberg 2007; Costa et al. 2010; Trizelia \& Nurdin 2010; Kafie et al. 2011).

Bari (2006) melaporkan bahwa B. bassiana menyebabkan tingkat kematian $C$. formicarius yang tinggi, yaitu mencapai $100 \%$. Eksplorasi terhadap berbagai isolat cendawan $B$. bassiana telah dilakukan oleh Prayogo (2010) dan memperoleh tiga isolat yang cukup efektif karena mampu membunuh imago, larva, serta menggagalkan penetasan telur C. formicarius hingga 100\%. Selain itu, Faishol (2011) juga mengemukakan bahwa aplikasi B. bassiana efektif mengendalikan $C$. formicarius hingga $80 \%$ pada kerapatan konidia $10^{9} / \mathrm{ml}$.

Pengendalian $C$. formicarius menggunakan cendawan entomopatogen $B$. bassiana masih belum banyak diterapkan di Indonesia. Hal ini terjadi karena petani belum mendapatkan informasi yang valid mengenai keefektifan, cara, dan waktu aplikasi $B$. bassiana dalam mengendalikan C. formicarius pada ubi jalar. Penelitian ini bertujuan untuk mendapatkan teknik pengendalian $C$. formicarius menggunakan cendawan entomopatogen $B$. bassiana yang efektif dan efisien. 


\section{BAHAN DAN METODE}

Penelitian dilaksanakan pada bulan Juni-Oktober 2014 di kebun percobaan Muneng, Probolinggo, Jawa Timur. Rancangan yang digunakan adalah rancangan acak kelompok dengan lima perlakuan dan diulang tiga kali. Pengelompokan dilakukan karena adanya keragaman intensitas cahaya akibat naungan. Perlakuannya adalah stek direndam suspensi konidia $B$. bassiana selama 30 menit sebelum tanam (P1), aplikasi suspensi konidia $B$. bassiana ke tanah pada umur 2, 4, 6, 8, 10, dan 12 minggu setelah tanam (MST) (P2), stek direndam suspensi konidia $B$. bassiana selama 30 menit sebelum tanam ditambah aplikasi suspensi konidia B. bassiana ke tanah pada umur 2, 4, 6, 8, 10, dan 12 MST (P3), aplikasi insektisida kimia berbahan aktif chlorpyrifos interval 1 minggu (P4), dan kontrol (tanpa aplikasi B. bassiana maupun insektisida kimia) (P5). Aplikasi suspensi konidia B. bassiana dan insektisida kimia dilakukan dengan cara disemprot pada permukaan tanah dekat pangkal batang tanaman ubi jalar. Data yang diperoleh dianalisis ragam dan dilanjutkan dengan uji beda nyata terkecil pada taraf 5\%.

\section{Persiapan tanaman untuk perlakuan}

Ubi jalar ditanam pada petak yang berukuran $4 \mathrm{~m}$ x $5 \mathrm{~m}$ per perlakuan per ulangan dengan jarak tanam di dalam baris $20 \mathrm{~cm}$ dan jarak antar baris $1 \mathrm{~m}$. Setiap lubang ditanam satu stek ubi jalar. Total tanaman per petak adalah 100 tanaman. Tanaman dipupuk dengan $200 \mathrm{~kg}$ Urea $+100 \mathrm{~kg} \mathrm{SP} 36+100$ $\mathrm{kg} \mathrm{KCl} / \mathrm{ha}(1 / 3$ dosis Urea dan $\mathrm{KCl}+$ seluruh SP36 diberikan saat tanam, 2/3 Urea dan $\mathrm{KCl}$ diberikan pada tanaman berumur 1,5 bulan).

\section{Perbanyakan B. bassiana}

Isolat cendawan $B$. bassiana yang memiliki virulensi tertinggi hasil penelitian pada tahun 2011 dikulturkan pada media potato dextrose agar (PDA). Pada umur 21 hari setelah inokulasi (HSI), konidia yang terbentuk ditumbuhkan pada media jagung di laboratorium. Pada umur $21 \mathrm{HSI}$, konidia $B$. bassiana yang terbentuk dicampur dengan air, selanjutnya dihitung kerapatan konidianya dengan menggunakan haemocytometer hingga memperoleh kerapatan konidia $10^{7} / \mathrm{ml}$. Suspensi konidia $B$. bassiana sebelum diaplikasikan ditambahkan Tween 80 sebanyak $2 \mathrm{ml} / 1$ sebagai bahan perata dan perekat.

\section{Perlakuan dan aplikasi $B$. bassiana}

Aplikasi suspensi konidia B. bassiana diberikan ke dalam tanah dengan cara menyemprotkan suspensi pada permukaan tanah atau pangkal batang tanaman ubi jalar. Setiap tanaman diberikan sebanyak $10 \mathrm{ml}$ suspensi $B$. bassiana yang diaplikasikan sesuai perlakuan dan dilakukan pada pagi hari pukul 07:00 WIB. Perlakuan pencelupan stek ubi jalar dilakukan dengan merendam pangkal stek dalam suspensi konidia $B$. bassiana $10^{7} / \mathrm{ml}$ selama 30 menit sebelum tanam. Dosis aplikasi cendawan $B$. bassiana sesuai dengan volume semprot 400-600 1/ha yang mengandung konidia $10^{7} / \mathrm{ml}$.

\section{Pengumpulan dan analisis data}

Pengamatan dilakukan pada saat panen. Sebanyak lima rumpun tanaman contoh dipilih secara acak untuk selanjutnya diamati populasi telur, larva, pupa, dan imago C. formicarius, tingkat kerusakan umbi, jumlah umbi, bobot umbi, dan ukuran umbi. Komponen hasil yang diamati adalah jumlah tanaman yang dipanen serta bobot umbi per plot. Tingkat kerusakan umbi akibat $C$. formicarius dinilai dari intensitas serangan $C$. formicarius. Skor serangan C. formicarius dibagi dalam 5 tingkatan sebagai berikut:

0 : tanaman tidak terserang dan tanpa gejala gerekan pada umbi.

1: umbi terserang $C$. formicarius ditandai dengan gejala adanya lubang bekas gerekan C. formicarius dengan intensitas $>0-25 \%$.

2: umbi terserang $C$. formicarius ditandai dengan gejala adanya lubang bekas gerekan $C$. formicarius dengan intensitas $>25-50 \%$.

3: umbi terserang $C$. formicarius ditandai dengan gejala adanya lubang bekas gerekan C. formicarius dengan intensitas $>50-75 \%$.

4: umbi terserang $C$. formicarius ditandai dengan gejala adanya lubang bekas gerekan $C$. formicarius dengan intensitas $\geq 76 \%$.

Selanjutnya hasil skor umbi tanaman sampel digunakan untuk menghitung intensitas serangan C. formicarius pada tanaman dengan menggunakan rumus yang dikembangkan oleh Zuraida et al. (2005) dan Man et al. (2011): 


$$
\mathrm{I}=\sum \frac{\text { ni } \mathrm{x} \text { vi }}{\mathrm{ZN}} \times 100 \% \text {, dengan }
$$

I: intensitas serangan (\%); ni: banyaknya umbi yang menunjukkan skor ke-i; vi: skor umbi ke-i (i $=0-4) ; \mathrm{Z}$ : skor tertinggi (4); N: banyaknya umbi yang diamati

\section{HASIL}

Pengaruh teknik pengendalian terhadap populasi $C$. formicarius dan tingkat kerusakan pada umbi

Hasil analisis ragam menunjukkan bahwa perlakuan berbagai jenis teknik pengendalian berpengaruh nyata terhadap populasi larva, imago, dan tingkat kerusakan umbi yang diakibatkan oleh C. formicarius, namun tidak berbeda nyata pada populasi telur dan pupa (Tabel 1). Populasi telur C. formicarius tertinggi terdapat pada perlakuan kontrol (P5). Sedangkan, populasi telur terendah terdapat pada perlakuan perendaman stek ubi jalar pada suspensi konidia $B$. bassiana selama 30 menit sebelum tanam yang dilanjutkan dengan aplikasi suspensi konidia $B$. bassiana ke tanah pada umur 2, 4, 6, 8, 10, dan 12 MST (P3).

Populasi larva tertinggi juga terdapat pada perlakuan kontrol (P5). Sedangkan, populasi larva terendah terdapat pada perlakuan penyemprotan dengan $B$. bassiana pada permukaan tanah atau pangkal batang pada umur 2, 4, 6, 8, 10, dan 12 MST (P2). Namun, tidak berbeda nyata dengan perlakuan perendaman stek ubi jalar ke dalam suspensi B. bassiana selama 30 menit sebelum tanam yang dilanjutkan dengan penyemprotan $B$. bassiana ke tanah pada umur 2, 4, 6, 8, 10, dan 12 MST (P3).

Populasi pupa tertinggi terdapat pada perlakuan aplikasi insektisida kimia. Sedangkan, populasi pupa terendah terdapat pada perlakuan penyemprotan $B$. bassiana interval dua minggu pada permukaan tanah dan tidak berbeda nyata dengan perlakuan aplikasi suspensi konidia $B$. bassiana ke tanah pada umur 2, 4, 6, 8, 10, dan 12 MST, perendaman stek ubi jalar pada suspensi konidia $B$. bassiana selama 30 menit sebelum tanam, dan kontrol. Populasi imago tertinggi terdapat pada perlakuan kontrol, yaitu 4 individu per rumpun. Sedangkan, pada perlakuan aplikasi B. bassiana pada permukaan tanah atau pangkal batang ubi jalar pada umur 2, 4, 6, 8, 10, dan 12 MST tidak ditemukan imago.

Teknik pengendalian berpengaruh secara nyata terhadap tingkat kerusakan umbi oleh $C$. formicarius (Tabel 1). Tingkat kerusakan umbi tertinggi terdapat pada perlakuan kontrol, yaitu mencapai 53,33\% per tanaman. Sedangkan, tingkat kerusakan umbi yang terendah terdapat pada perlakuan aplikasi suspensi konidia $B$. bassiana ke tanah pada umur 2, 4, 6, 8, 10, dan 12 MST. Namun, tidak berbeda nyata dengan perlakuan perendaman stek ubi jalar pada suspensi konidia B. bassiana selama 30 menit sebelum tanam yang dikombinasikan dengan aplikasi suspensi konidia B. bassiana ke tanah pada umur $2,4,6,8,10$, dan 12 MST.

Tabel 1. Populasi telur, larva, pupa, dan imago Cylas formicarius serta tingkat kerusakan umbi pada berbagai perlakuan teknik pengendalian

\begin{tabular}{lccccc}
\hline \multirow{2}{*}{ Perlakuan } & \multicolumn{3}{c}{ Populasi Cylas formicarius per tanaman } & $\begin{array}{c}\text { Tingkat } \\
\text { kerusakan umbi } \\
(\%)\end{array}$ \\
\cline { 2 - 5 } P1 & 4,00 & $7,67 \mathrm{~b}$ & 0,00 & Imago (individu) & $23,33 \mathrm{~b}$ \\
P2 & 1,00 & $1,33 \mathrm{c}$ & 0,00 & $1,40 \mathrm{~b}$ & $5,83 \mathrm{c}$ \\
P3 & 0,67 & $1,73 \mathrm{c}$ & 0,00 & $0,13 \mathrm{c}$ & $8,60 \mathrm{bc}$ \\
P4 & 0,73 & $4,47 \mathrm{bc}$ & 0,13 & $0,47 \mathrm{bc}$ & $11,67 \mathrm{bc}$ \\
P5 & 4,33 & $19,20 \mathrm{a}$ & 0,07 & $3,93 \mathrm{bc}$ & $53,33 \mathrm{a}$ \\
\hline F & 2,735 & 34,273 & 2,285 & 12,381 & 13,790 \\
Db & 4,8 & 4,8 & 4,8 & 4,8 & 4,8 \\
P & $\mathrm{p}<0,105$ & $\mathrm{p}<0,000$ & $\mathrm{p}<0,148$ & $\mathrm{p}<0,001$ & $\mathrm{p}<0,001$ \\
\hline Ang & Larva (individu) & Pupa (individu) &
\end{tabular}

Angka sekolom yang diikuti oleh huruf yang sama tidak berbeda nyata pada taraf 5\%. 


\section{Pengaruh teknik pengendalian terhadap} komponen hasil ubi jalar

Hasil analisis ragam menunjukkan bahwa perlakuan berbagai teknik pengendalian $C$. formicarius berpengaruh nyata terhadap bobot umbi ubi jalar per plot. Namun, tidak berpengaruh signifikan terhadap jumlah tanaman yang dipanen, jumlah umbi, bobot umbi, panjang umbi, serta diameter umbi (Tabel 2).

Bobot umbi ubi jalar pada masing-masing plot perlakuan berkisar antara 20,3-44,2 kg. Bobot umbi tertinggi terdapat pada perlakuan perendaman stek ubi jalar pada suspensi konidia $B$. bassiana selama 30 menit sebelum tanam (P1). Namun, tidak berbeda nyata dengan bobot umbi pada perlakuan aplikasi suspensi konidia $B$. bassiana ke tanah pada umur 2, 4, 6, 8, 10, dan 12 MST dan perlakuan aplikasi insektisida. Sedangkan, pada perlakuan kontrol, bobot umbi tercatat lebih rendah dibandingkan dengan keempat perlakuan lainnya.

Teknik pengendalian $C$. formicarius tidak berpengaruh nyata terhadap jumlah umbi per tanaman. Jumlah umbi per tanaman yang tertinggi terdapat pada perlakuan aplikasi suspensi konidia B. bassiana ke tanah pada umur 2, 4, 6, 8, 10, dan 12 MST. Sedangkan, jumlah umbi per tanaman yang terendah terdapat pada perlakuan kontrol. Selain itu, bobot umbi per tanaman yang tertinggi terdapat pada perlakuan perendaman stek ubi jalar pada suspensi konidia $B$. bassiana selama 30 menit sebelum tanam dan bobot umbi yang terendah terdapat pada perlakuan aplikasi insektisida kimia.

Panjang umbi ubi jalar pada perlakuan aplikasi berbagai teknik pengendalian $C$. formicarius ber- kisar antara 12,0-14,2 cm/umbi. Umbi yang menunjukkan ukuran terpanjang terdapat pada perlakuan kontrol. Namun, tidak berbeda nyata dengan panjang umbi terendah yang terdapat pada perlakuan aplikasi suspensi konidia $B$. bassiana ke tanah pada umur 2, 4, 6, 8, 10, dan 12 MST. Hal serupa juga terlihat dari diameter umbi. Umbi yang menunjukkan diameter terbesar terdapat pada perlakuan tanpa pengendalian dan perlakuan perendaman stek ubi jalar pada suspensi konidia B. bassiana selama 30 menit sebelum tanam yang dilanjutkan dengan aplikasi suspensi konidia $B$. bassiana ke tanah pada umur 2, 4, 6, 8, 10, dan 12 MST. Diameter umbi pada kedua perlakuan tersebut tidak berbeda nyata dengan diameter umbi pada perlakuan aplikasi suspensi konidia $B$. bassiana ke tanah pada umur 2, 4, 6, 8, 10, dan $12 \mathrm{MST}$, yang merupakan umbi dengan diameter terkecil.

\section{PEMBAHASAN}

Perbedaan populasi C. formicarius pada umbi ubi jalar disebabkan oleh perbedaan teknik pengendalian yang diaplikasikan. Populasi $C$. formicarius terendah terdapat pada perlakuan aplikasi suspensi konidia $B$. bassiana pada permukaan tanah sejak tanaman berumur 2-12 MST, yaitu 2 individu. Diduga bahwa $B$. bassiana sangat persisten di tanah dalam jangka waktu yang lama sehingga konidianya mampu menginfeksi tubuh imago $C$. formicarius yang akan menyerang umbi ubi jalar.

Tanah merupakan media tumbuh yang kondusif untuk terjadinya infeksi konidia cendawan

Tabel 2. Jumlah tanaman panen, bobot umbi, jumlah umbi, dan ukuran umbi ubi jalar pada berbagai perlakuan teknik pengendalian

\begin{tabular}{lcccccc}
\hline Perlakuan & $\begin{array}{c}\text { Jumlah tanaman } \\
\text { dipanen (tanaman) }\end{array}$ & $\begin{array}{c}\text { Bobot umbi// } \\
\text { plot (kg) }\end{array}$ & $\begin{array}{c}\text { Jumlah umbi/ } \\
\text { tanaman } \\
\text { (buah) }\end{array}$ & $\begin{array}{c}\text { Bobot umbi/ } \\
\text { tanaman }(\mathrm{g})\end{array}$ & $\begin{array}{c}\text { Panjang } \\
\text { umbi (cm) }\end{array}$ & $\begin{array}{c}\text { Diameter } \\
\text { umbi (cm) }\end{array}$ \\
\hline P1 & 72,3 & $44,2 \mathrm{a}$ & 2,0 & 700,7 & 14,1 & 5,3 \\
P2 & 74,3 & $37,7 \mathrm{a}$ & 2,6 & 680,9 & 12,0 & 4,4 \\
P3 & 71,7 & $33,0 \mathrm{ab}$ & 2,1 & 573,5 & 14,0 & 5,4 \\
P4 & 73,0 & $36,2 \mathrm{a}$ & 2,5 & 571,0 & 13,5 & 5,1 \\
P5 & 73,0 & $20,3 \mathrm{~b}$ & 1,8 & 659,2 & 14,2 & 5,4 \\
\hline F & 0,191 & 3,636 & 1,439 & 1,402 & 0,823 & 0,108 \\
Db & 4,8 & 4,8 & 4,8 & 4,8 & 4,8 & 4,8 \\
P & - & $\mathrm{p}>0,056$ & $\mathrm{p}>0,305$ & $\mathrm{p}>0,316$ & - & $\mathrm{p}>0,424$ \\
\hline
\end{tabular}

Angka sekolom yang diikuti oleh huruf yang sama tidak berbeda nyata pada taraf $5 \%$. 
entomopatogen karena suhu dan kelembapannya relatif seimbang (Ansari et al. 2008). Pada penelitian ini, aplikasi B. bassiana dilakukan dengan kerapatan konidia $10^{7} / \mathrm{ml}$ dan frekuensi aplikasi hingga 8 kali selama musim tanam. Hal ini diduga menjadi penyebab banyaknya imago $C$. formicarius yang terinfeksi $B$. bassiana sebelum berhasil meletakkan telur pada pangkal batang atau kulit umbi ubi jalar sehingga populasi telur, larva, dan pupa rendah. Hasil penelitian Krreutz et al. (2004) menunjukkan bahwa distribusi cendawan entomopatogen terjadi secara horizontal dan semakin banyak konidia yang dihasilkan semakin besar pula terjadi distribusi patogen sehingga semakin cepat terjadi epizooti. Selain itu, Ansari et al. (2008) juga melaporkan bahwa semakin rendah kerapatan konidia yang diaplikasikan membutuhkan waktu yang lama untuk terjadinya infeksi pada tubuh serangga. Apabila imago $C$. formicarius terinfeksi $B$. bassiana maka berpeluang besar untuk mati sehingga tidak dapat meletakkan telur pada umbi.

Pada perlakuan aplikasi insektisida (P4), populasi $C$. formicarius baik telur, larva, pupa, maupun imago terlihat lebih tinggi dibandingkan dengan aplikasi $B$. bassiana. Aplikasi insektisida yang dilakukan setiap minggu ini justru menyebabkan resistensi pada $C$. formicarius. Imago C. formicarius memiliki ketahanan yang tinggi terhadap insektisida sehingga tetap bertahan hidup dan meletakkan telurnya pada umbi ubi jalar. Selain itu, aplikasi pemupukan yang dilakukan untuk memelihara kesuburan tanaman menjadikan tanah tempat tumbuhnya ubi jalar mengandung bahan organik yang tinggi. Menurut Kepler \& Bruck (2006), aktifitas imidaclorprid dan jenis insektisida lainnya akan terhambat apabila diaplikasikan ke tanah dengan kandungan bahan organik yang tinggi. Di duga, kondisi ini mengakibatkan insektisida tidak dapat bekerja secara optimal dalam mengendalikan C. formicarius.

Tingkat kerusakan umbi yang rendah terlihat pada perlakuan aplikasi suspensi konidia $B$. bassiana secara tunggal ke tanah pada umur 2, 4, 6, 8, 10, dan 12 MST (P2), sedikit lebih rendah dibandingkan dengan perlakuan perendaman stek ubi jalar pada suspensi konidia B. bassiana selama 30 menit sebelum tanam yang dilanjutkan dengan aplikasi suspensi konidia $B$. bassiana ke tanah pada umur 2, 4, 6, 8, 10, dan 12 MST (P3). Diduga, suspensi konidia B. bassiana yang diaplikasikan ke tanah telah menginfeksi imago C. formicarius. Imago yang terinfeksi berat akan mati, sedangkan yang terinfeksi ringan masih dapat bertahan dan meletakkan telur pada pangkal batang atau kulit umbi. Namun, imago C. formicarius yang telah kontak dengan $B$. bassiana akan terinfeksi oleh toksin dari $B$. bassiana sehingga produksi telur dan larva yang berhasil menetas dari telur juga terinfeksi toksin B. bassiana. Hal ini menyebabkan telur tidak menetas dan larva tidak dapat berkembang serta menyerang umbi secara sempurna. Glare et al. (2002) melaporkan bahwa imago serangga dari ordo Coleoptera yang terinfeksi oleh $B$. bassiana akan mentransfer spora cendawan tersebut ke larva dan menyebabkan kematian larva 50-100\%. Imago yang terinfeksi B. bassiana dapat menularkan infeksi ke serangga lain dan ke generasi berikutnya di lapang (Dembilio et al. 2010; Reddy et al. 2014). Aplikasi $B$. bassiana di tanah sangat efektif karena dapat menekan populasi $C$. formicarius sehingga tingkat kerusakan umbi ubi jalar juga semakin rendah. Gouli et al. (2008) mengemukakan bahwa aplikasi cendawan entomopatogen di tanah merupakan pengendalian biologi yang efektif. Pada penelitian ini, perlakuan P2 lebih efisien dibandingkan dengan perlakuan P3 karena dengan hanya aplikasi tunggal atau tanpa mengombinasikan dengan perendaman stek ubi jalar sesaat sebelum tanam, populasi larva yang masuk ke umbi dapat ditekan sehingga kerusakan umbi yang dihasilkan rendah meskipun populasi telur dan pupa tidak menunjukkan perbedaan yang signifikan.

Perlakuan perendaman stek ubi jalar pada suspensi konidia $B$. bassiana selama 30 menit sebelum tanam (P1) menunjukkan tingkat kerusakan umbi yang tinggi, yaitu 23,33\% apabila dibandingkan dengan perlakuan yang lain selain kontrol. Hal ini disebabkan populasi larva C. formicarius yang ditemukan dalam umbi pada perlakuan P1 ini yang juga tinggi. Vega et al. (2008) dan Quesada-Moraga et al. (2009) mengemukakan bahwa perendaman stek merupakan salah satu metode yang kurang sensitif dan ada kemungkinan terdapat cendawan lainnya yang bersifat endofit pada potongan tanaman selain $B$. bassiana. Adanya cendawan endofit 
pada bagian tanaman akan mengurangi persistensi B. bassiana yang selanjutnya mempengaruhi perkecambahan konidia $B$. bassiana sehingga proses penetrasi ke dinding tubuh $C$. formicarius terhambat bahkan tidak terjadi. Inokulasi $B$. bassiana menggunakan metode perendaman stek kurang efektif mengendalikan $C$. formicarius karena memungkinkan adanya persaingan dengan cendawan endofit yang tidak diketahui keberaannya sebelumnya.

Bobot umbi pada perlakuan kontrol (P5) rendah karena serangan $C$. formicarius yang tinggi, yaitu mencapai $53,33 \%$. Imago C. formicarius leluasa untuk meletakkan telurnya pada pangkal batang atau kulit umbi di perlakuan kontrol (P5) kerana tidak ada aplikasi B. bassiana ataupun insektisida kimia. Telur $C$. formicarius yang tidak terinfeksi oleh konidia $B$. bassiana dapat menetas, selanjutnya larva dapat masuk ke dalam umbi dengan menggerek dan merusak umbi secara maksimal.

Bobot umbi per plot terlihat tinggi pada perlakuan perendaman stek ubi jalar pada suspensi konidia $B$. bassiana, namun tidak berbeda nyata dengan bobot umbi pada perlakuan aplikasi suspensi konidia $B$. bassiana ke tanah. Hal ini disebabkan karena larva $C$. formicarius yang meyerang umbi jumlahnya sangat sedikit sehingga kerusakan yang ditimbulkan juga rendah. Penggunaan $B$. bassiana untuk mengendalikan C. formicarius lebih efektif dibandingkan dengan menggunakan insektisida kimia. Cendawan $B$. bassiana mampu menginfeksi berbagai stadia $C$. formicarius mulai dari stadia telur, larva, maupun imago dengan tingkat efikasi yang cukup tinggi, sedangkan aplikasi insektisida kimia hanya membunuh stadia imago tanpa menularkan infeksi terhadap generasinya sehingga telur akan menetas dan larva akan menggerek umbi serta menimbulkan kerusakan umbi yang lebih besar. Oleh karena itu, pengendalian biologi penggerek ubi jalar menggunakan cendawan $B$. bassiana mempunyai prospek yang lebih baik karena selain efektif juga mendukung sistem pertanian yang ramah lingkungan karena dapat menekan paparan residu insektisida baik di produk yang dihasilkan maupun di lingkungan.

\section{KESIMPULAN}

Teknik pengendalian C. fomicarius dengan mengaplikasikan suspensi konidia cendawan entomopatogen $B$. bassiana pada permukaan tanah atau bagian pangkal batang ubi jalar pada umur 2, 4, 6, 8, 10, dan 12 MST adalah efektif dan efisien. Teknik tersebut berhasil menekan populasi $C$. formicarius pada umbi dan mampu mengurangi kerusakan umbi ubi jalar hingga 47,5\% dibandingkan dengan kontrol. Teknik tersebut juga lebih efisien dari segi waktu, tenaga, dan biaya bila dibandingkan dengan teknik perendaman stek yang dikombinasikan dengan penyemprotan pada permukaan tanah. Selain itu, aplikasi B. bassiana untuk mengendalikan $C$. formicarius dapat menekan residu insektisida sehingga lebih aman terhadap lingkungan.

\section{UCAPAN TERIMA KASIH}

Terima kasih kami sampaikan kepada Badan Litbang Pertanian yang telah memberikan dana melalui DIPA untuk terlaksananya penelitian ini hingga selesai.

\section{DAFTAR PUSTAKA}

Ahdiaty I. 2013. Pengaruh Umur Cendawan Beauveria bassiana (Balsamo) Vuillemen terhadap Infektivitasnya pada Cylas formicarius (Fabricius) (Coleoptera: Brentidae). Skripsi. Bogor: Institut Pertanian Bogor.

Ansari MA, Brownbridge M, Shah FA, Butt TM. 2008. Efficacy of entomopathogenic fungi against soil-dwelling life stages of western flower thrips, Frankliniella occidentalis, in plant-growing media. Entomologia Experimentalis et Applicata 127:80-87. doi: http://dx.doi.org/10.1111/j.15707458.2008.00674.x.

Bari D. 2006. Keefektifan Beberapa Isolat Cendawan Entomopatogen Beauveria bassiana (Balsamo) Vuillemin terhadap Hama Boleng Cylas formicarius (Fabr.) (Coleoptera: Curculionidae) di Laboratorium. Skripsi. Bogor: Institut Pertanian Bogor. 
Capinera JL. 1998. Sweet Potato Weevil, Cylas formicarius (Fabricius). Florida: Institute of Food and Agricultural Sciences. University of Florida.

Chiranjeevi C, Reddy DDR, Gour TB, Reddy YN, Sultana A. 2003. Comparative biology of sweet potato weevil Cylas formicarius Fabricius on vines and tubers of sweet potato. Journal of Research Angrau 31:17-21.

Costa J, Alves LFA, Daros AA. 2010. Safety of Beauveria bassiana (Bals.) Vuillemen to Galus domesticus L. Brazilian Archives of Biology and Technology 53:465-471. doi: http://dx.doi. org/10.1590/S1516-89132010000200027.

Dembilio O, Moraga EQ, Alvarez CS, Jacas JA. 2010. Potential of an indigenous strain of the entomopathogenic fungus Beauveria bassiana as a biological control agent against the Red Palm Weevil, Rhynchophorus ferrugineus. Journal of Invertebrate Pathology 104:214-221. doi: http:// dx.doi.org/10.1016/j.jip.2010.04.006.

Faishol A. 2011. Pengujian Keefektifan Cendawan Metarhizium brunneum Petch terhadap Hama Ubi Jalar Cylas formicarius Fabricius (Coleoptera: Brentidae). Skripsi. Bogor: Institut Pertanian Bogor.

Gayathri G, Balasubramanian C, Moorthi PV, Kubendran T. 2010. Larvicidal potential of Beauveria bassiana (Balsamo) Vuillemin and Paecilomyces fumosoroseus (Wize.) Brown and Smith on Culex quinquefasciatus (Say.). Journal of Biopesticides 3:147-151.

Glare TR, Placer C, Nelson TL, Reay SD. 2002. Potential of Beauveria and Metarhizium as control agents of pinhole borers (Platypus spp.). New Zealand Plant Protection 55:73-79.

Gouli V, Gouli S, Skinner M, Shternshis MV. 2008. Effect of the entomopathogenic fungi on mortality and injury level of western flower thrips, Frankliniella occidentalis. Archives of Phytopathology and Plant Protection 4:37-47.

Hansen LS, Steenberg T. 2007. Combining larval parasitoid and an entomopathogenic fungus for biological control of Sitophilus granaries (Coleoptera: Curculionidae) in stored grain. Biological control 40:237-242. doi: http://dx. doi.org/10.1016/j.biocontrol.2006.09.012.

Kafie L, Wu WJ, Kao SS, Shin CJ. 2011. Efficacy of Beauveria bassiana against the red imported fire ant Solenopsis invicta (Hymenoptera: Formicidae) in Taiwan. Pest Management Science 67:14321-1438.

Kandori I, Kimura T, Tsumuki H, Sugimoto T. Cold tolerance of the sweet potato weevil, Cylas formicarius (Fabricius) (Coleoptera: Brentidae), from the Southwestern Islands of Japan. Applied Entomology and Zoology 41:217-226. doi: http:/ doi.org/10.1303/aez.2006.217.

Kepler RM, Bruck DJ. 2006. Examination of the interaction between the black vine weevil (Coleoptera: Curculionidae) and an entomopathogenic fungus reveals a new tritrophic interaction. Environmental Entomology 35:10211029. doi: http://dx.doi.org/10.1603/0046-225X35.4.1021.

Krreutz J,Zimmermann G, VaupelO. 2004. Horizontal transmission of the entomopathogenic fungus Beauveria bassiana among the spruce bark beetle Ips typographus (Coleoptera: Scolytidae) in the laboratory and under field conditions. Biocontrol Science and Technology 14:837-848. doi: http:// dx.doi.org/10.1080/788222844.

Leng PH, Reddy GVP. 2012. Bioactivity of selected ecofriendly pesticides against Cylas formicarius (Coleoptera: Brentidae). Florida Entomological Society 95:1040-1047. doi: http://dx.doi.org/10. 1653/024.095.0433.

Man YS, Ndiwa ASS, Arsa IGBA. 2011. Tingkat ketahanan klon potensial ubi jalar lokal asal NTT terhadap hama lanas (Cylas formicarius Fab.). Jurnal HPT Tropika 11:139-146.

Meyling NV, Eilenberg J. 2007. Ecology of the entomopathogenic fungi Beauveria bassiana and Metarhizium anisopliae in temperate agroecosystems: Potential for conservation biological control. Journal of Microbiology 104: 1401-1411. doi: http://dx.doi.org/10.1016/j.bio control.2007.07.007.

Nonci N. 2005. Bioekologi dan pengendalian kumbang Cylas formicarius Fabricus (Coleoptera: Curculionidae). Jurnal Litbang Pertanian 24: 63-69.

Norris RF, Caswell-Chen EP, Kogan M. 2003. Concept in Integrated Pest Management. New Jersey: Prentice Hall.

Prayogo Y. 2012. Virulensi beberapa isolate cendawan entomopatogen Beauveria bassiana (Balsamo) untuk mengendalikan penggerek ubi jalar Cylas formicarius. Di dalam: Widjono A, Hermanto, Nugrahaeni N, Rahmiana AA, Suharsono, Rozi F, Ginting E, Taufiq A, Harsono A, Prayogo Y, Yusnawan E (Ed.), Prosiding Seminar Nasional Hasil Penelitian Tanaman Aneka Kacang dan Umbi (Bogor, 15 Nopember 2011). hlm. 738754. Bogor: Puslitbang Tanaman Pangan.

Quesada-Moraga E, Munoz-Ledesma FJ, Santiago A, Lvarez C. 2009. Systemic protection of Papaver somniferum L. against Iraella luteipes (Hyme- 
noptera: Cynipidae) by an endophytic strain of Beauveria bassiana (Ascomycota: Hypocreales). Environmental Entomology 38:723-730. doi: http://dx.doi.org/10.1603/022.038.0324.

Ratissa DA. 2011. Keefektifan Cendawan Entomopatogen Beauveria bassiana (Balsamo) Vuillemen terhadap Cylas formicarius (Fabricius) (Coleoptera: Brentidae) dan Pengaruhnya pada Keperidian. Skripsi. Bogor: Institut Pertanian Bogor.

Reddy GVP, Zihua Z, Richard AH. 2014. Laboratory and field efficacy of entomopathogenic fungi for the management of the sweetpotato weevil, Cylas formicarius (Coleoptera: Brentidae). Journal of Invertebrate Pathology 122:10-15. doi: http:// dx.doi.org/10.1016/j.jip.2014.07.009.

Sharah HA, Sodangi BI, Abdurrahman M. 2012. The economic implication of Cylas spp. and rot organism infestation on the matketability of sweet potato (Ipomoea batatas L.) in three markets in Maiduguri Metropolis Barno State Nigeria. International Journal of Economic Development Research and Investment 3:32-38.
Tamuli AK, Gurusubramanium G. 2011. Entomopathogenicity of white muscardine fungus Beauveria bassiana (Bals.) Vuill. (Deuteromycotina: Hyphomycetes) (BBFF-135) agaisnt Odontotermes (Rambur) (Isoptera: Termitidae). Assam University Journal of Science \& Technology: Biological and Environmental Sciences 7:118-125.

Trizelia, Nurdin F. 2010. Virulence of entomopathogenic fungus Beauveria bassiana isolates to Crocidolomia pavonana (F.) (Lepidoptera: Crambidae). Agrivita 32: 254-262.

Vega FE, Posada F, Aime MC, Pava-Ripoll M, Infante F, Rehner SA. 2008. Entomopathogenic fungal endophytes. Biological Conservation 46:72-82. doi: http:/doi.org/10.1016/j.biocontrol.2008.01.008.

Zuraida N, Minantyorini, Koswanudin D. 2005. Penyaringan ketahanan plasma nutfah ubi jalar terhadap hama lanas. Buletin Plasma Nutfah 11:11-15. 